\title{
Mediterranean Alluviation: New Evidence from Archaeology
}

\author{
By J. L. BinTLIFF ${ }^{1}$
}

Summary. Detailed regional studies of dated alluvial formations in Greece confirm the Vita-Finzi alluviation cycle and favour climatic causation. A review of recent work in this field reveals substantial, if unexpected, support for the cycle, and archaeologists and geographers are urged to recognise its validity and concentrate on its very significant effects.

In 1963 and 1964 in Nature, C. Vita-Finzi summarised the results of his recent study of the recent development of the Mediterranean landscape (Vita-Finzi 1963, 1964). A full publication came with The Mediterranean Valleys in 1969 (Vita-Finzi 1969 ). In the latter work he elaborated on his basic thesis that the countries around that sea had witnessed two major phases of alluviation within the last 100,000 years.

Vita-Finzi supported his scheme with numerous examples of the two fills dated directly by archaeological artefacts, radiocarbon samples and topographical analysis. To the evidence from geomorphology he added historical references and the significant results of historical climatology, especially the work of Lamb (Lamb r966).

But despite the considerable importance of these natural events to the development of society and economy in southern Europe, no detailed criticism of the theory has appeared in the literature, while recently published field studies exhibit very inadequate attempts to replicate or challenge Vita-Finzi's findings.

Butzer's dismissal of the theory is summary and poorly documented, but it is possible to relate his early Würm 'pluvial' deposits to Vita-Finzi's 'Older Fill' (Butzer 1971, 309). In Greece, Wright, Loy and Yassoglou make little effort to connect their landscape studies with the proposed cyclical alluviation, though again in their work there is to be found data in agreement with the Vita-Finzi scheme (Loy 1967, 58-61; Loy and Wright 1972, 42; Yassoglou 1972, 175; Wright 1972, 197). In a case-study in south-west Greece, Loy has claimed evidence for irrigation agriculture on recent alluvial terraces in the second millennium bc (Loy 1967, 94-105). The location was re-examined by the author in 1974 , with the conclusion that Loy conflated distinct deposits of Tertiary, Pleistocene and historical age.

Of four field studies that seriously investigate similar landscape features and processes to those figuring in The Mediterranean Valleys, those of Eisma and Raphael on coastal aggradation are contradictory to Vita-Finzi only by virtue of a misinterpretation of his theory, and are discussed below. In the Drama Plain study of Davidson (I97I), significantly not a coastal location, local confirmation is conceded for the alluviation cycle. The detailed investigations by Paepe in Attica (Paepe 1969), though in apparent ignorance of the alluviation scheme, isolates a post-Hellenistic recent alluvium preceded by an 'interglacial' alluvial-colluvial formation with all the type-features of the Older Fill. The argument presented here, that the latter formation, elsewhere known as 'Red Beds', must

\footnotetext{
'Address: Department of Archaeology, University of Cambridge.
} 


\section{7. L. Bintliff. MEDIterRANEAN ALLUVIATION}

reflect warm interglacial climate (see also Butzer 1971, 306) finds little support amongst geologists today, and a cold wet climate is acceptable for the lithology and form of the beds. (Personal communication from Dr P. F. Friend, Dept. of Geology, Cambridge.)

In the last three years the author has carried out extensive fieldwork in Greece, to elucidate the interaction between landscape evolution and the development of prehistoric communities over the period 60,000 bc-A.D. 500 . Data from geology, geomorphology, pedology and tectonics were correlated in the field with the total archaeological evidence (see Bintliff, in press). The major study areas are shown in figure $\mathrm{I}$.

In all regions examined by the writer only two major depositional episodes of alluvium and alluvio-colluvium are apparent. Both exactly match the Older and Younger Fills of Vita-Finzi (1963, 1964, 1969), in lithology, topography, and the date of associated archaeological material. In figure 2 the main associations of alluvial fill and datable buildings or artefacts are shown.

The older fill universally overlies Pliocene or earlier formations, and descends steeply at the coast to a former (glacial) low sea-level. In agreement with previous reports of artefacts of Würm date recovered from its upper levels (Leroi-Gourhan and Chavaillon 1963 ; Sordinas 1969; VitaFinzi and Higgs 1966), a similar association was identified by the author and Mr. B. Drost at

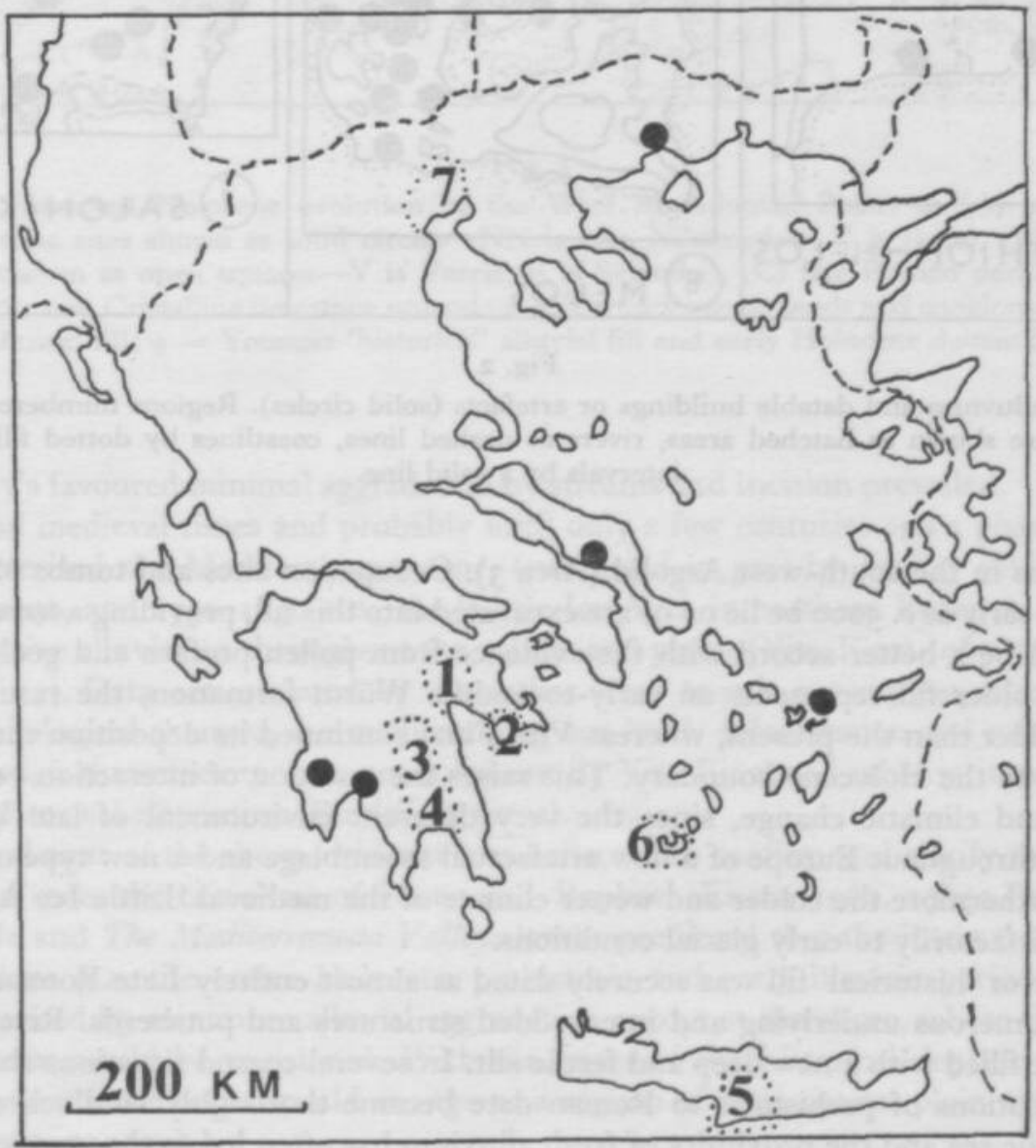

Fig. $x$

Location in Greece of regions studied (numbered) and individual localities (solid circles). 


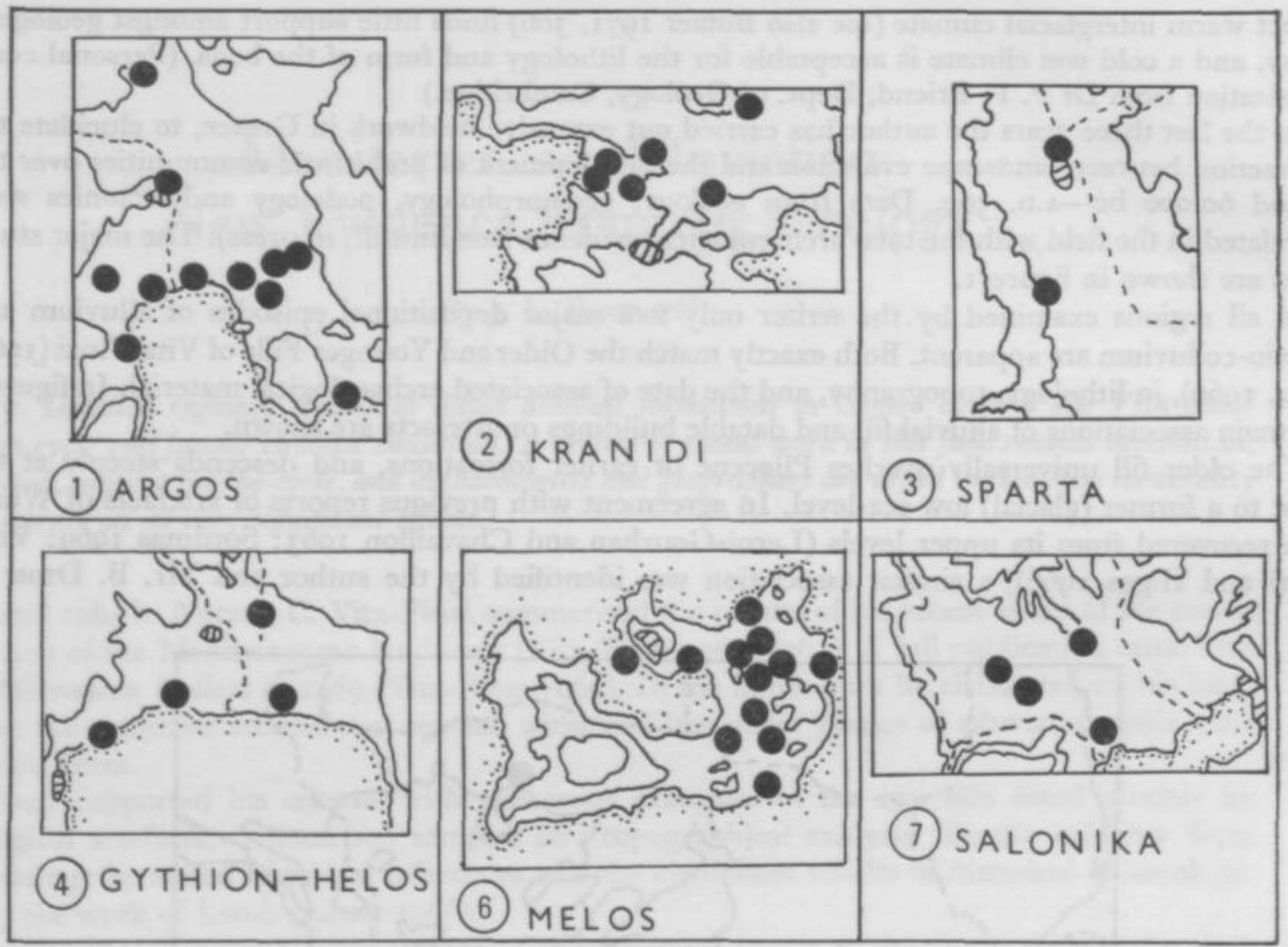

Fig. 2

Associations of alluvium and datable buildings or artefacts (solid circles). Regions numbered as in figure I, modern towns are shown as hatched areas, rivers as dashed lines, coastlines by dotted fill, major contour intervals by a solid line.

several locations in the south-west Argolid (Area 3). Occupation sites and tombs of Holocene age from at least as early as $c .5000 \mathrm{bc}$ lie on or are excavated into this fill, providing a terminus ante quem. There seems to be a better accord with the evidence from pollen profiles and geology, at least in Greece, if the older fill represents an early-to-middle Würm formation, the result of a climate moister and colder than the present, whereas Vita-Finzi continued its deposition through the cold, dry late Würm to the Holocene boundary. This raises the question of interaction between cultural discontinuity and climatic change, since the very different environment of late Würm sees the predominance throughout Europe of a new artefactual assemblage and a new type of Man (Bordes r968, 224). Furthermore the colder and wetter climate of the medieval 'Little Ice Age' would then correspond satisfactorily to early glacial conditions.

The younger or 'historical' fill was securely dated as almost entirely Late Roman and Medieval in age, from numerous underlying and interbedded structures and potsherds. River valleys, large and small, were filled with a new deep and fertile silt. In several coastal situations shore settlements and port installations of prehistoric to Roman date became thoroughly landlocked. The present distance from the sea and the proximity of fresh alluvium has often led to the erroneous interpretation that such sites were centres of irrigation agriculture.

There is now strong evidence that in the early to middle Holocene period a dry, warm climate 


\section{F. L. Bintliff. MEditerRanean alluviation}

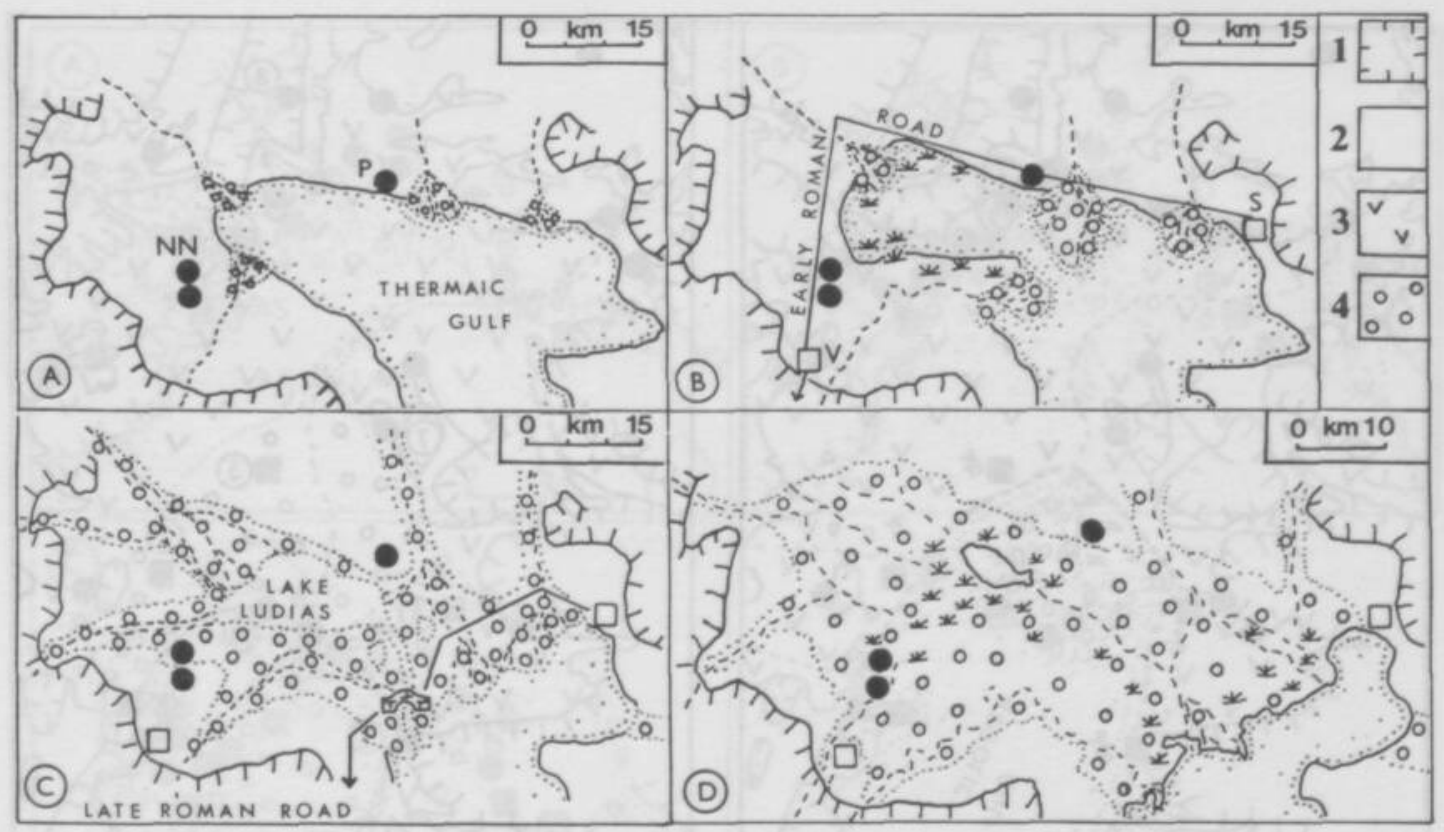

Fig. 3

Provisional reconstructed Holocene evolution of the West Macedonian Plain: in (A) prehistoric period (selected prehistoric sites shown as solid circles-NN is Nea Nikomedeia, $\mathrm{P}$ is Pella), (B) circa o b.c./a.d. (ancient towns shown as open squares-V is Verria, $\mathrm{S}$ is Salonika), (C) late Roman period circa 500 a.d.. (D) 1908 a.d. KEY : $1=$ Cristalline limestone upland; $2=$ Tertiary marls, sands and conglomerates; $3=$ Older alluvial fill; 4 = Younger 'historical' alluvial fill and early Holocene deltaic fill.

similar to today's favoured minimal aggradation by streams and incision prevailed. But throughout late Roman and medieval times and probably until only a few centuries ago a phase of cool, moist climate characterised the Mediterranean zone, (paralleled in part by similar cold wet conditions from c. 1200-1400, and 1550-1850 A.D., the 'Little Ice Age', in northern Europe), and resulting in deep and extensive alluviation throughout the valleys and plains (Vita-Finzi 1969, 96-100, 112-115; Lamb 1966, 8-12). Data accumulated by the author seem to rule out any major role in promoting these geomorphological changes, due to fluctuating sea-level, deforestation and soil erosion by man or goat, - although these factors were not ruled out by Vita-Finzi and other writers as contributory causes of the historical alluviation (Bintliff, in press).

In the general zone of the shore, evidence was collected to confirm and clarify the suggestions of Vita-Finzi, and meet the criticisms of Eisma and Raphael (Eisma 1962, 1964; Raphael 1973). In the 1964 article and The Mediterranean Valleys it was predicted that the interval between the two major depositions (i.e. the entire Holocene prehistoric and early historic periods) would be, as today, characterised by minimum alluvial aggradation except at the shore, where the outgrowth of deltaic sediments would be registered. With the onset of the historical deposition, this gradual accretion at major rivermouths would change to a regime of total coastal plain aggradation (VitaFinzi $1964 ; 1969,93,117)$.

Vita-Finzi neglected to provide field support for this process, and his inadequate treatment of coastal evolution is in part to blame for subsequent confusion amongst those describing similar 


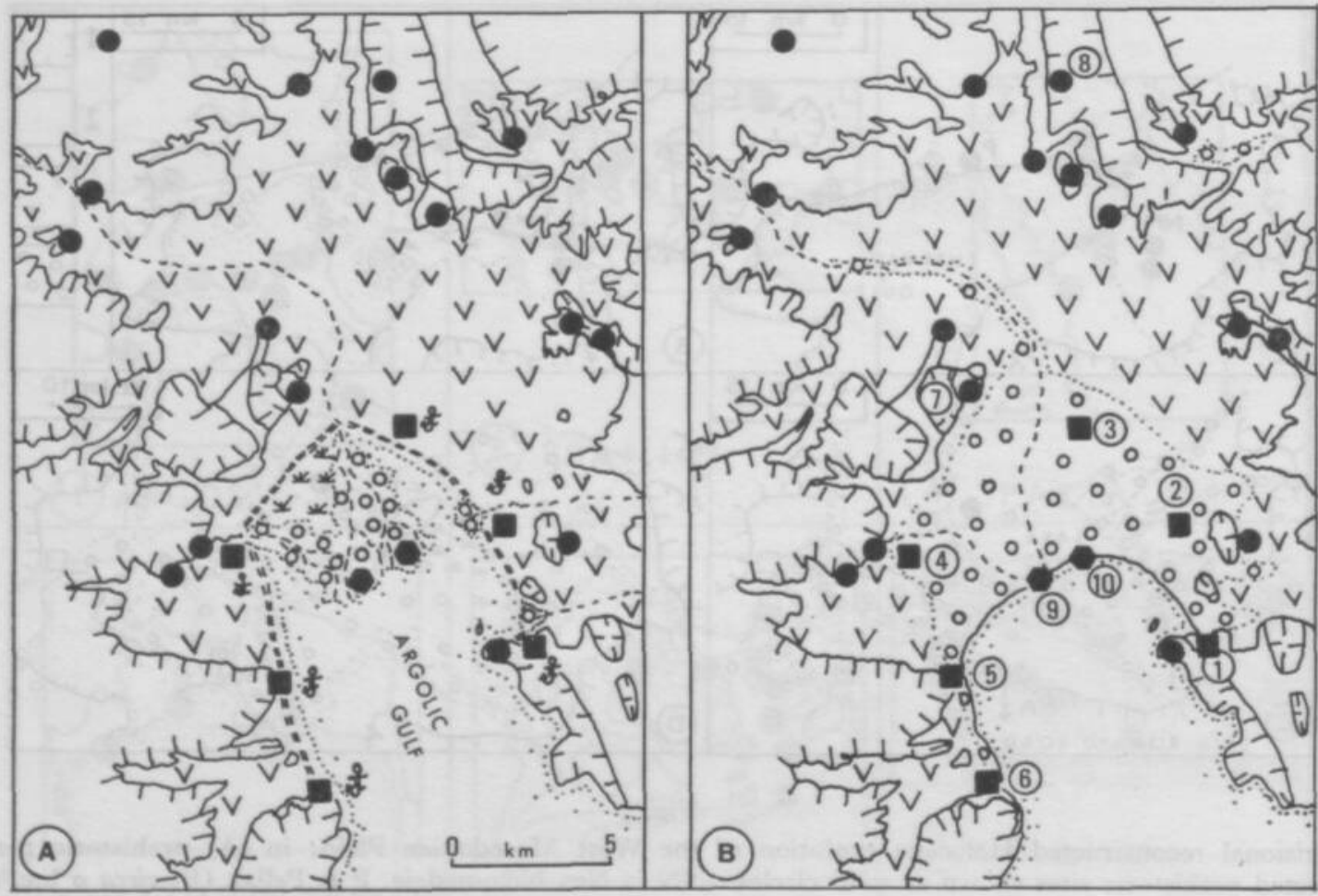

Fig. 4

Provisional reconstructed Holocene evolution of the Argos Plain. Geology symbols as in figure 3. Prehistoric inland sites are shown as solid circles, those formerly or still today on the coast are shown as solid squares (with anchor sign). Two Greco-Roman port sites are indicated by solid hexagons. Site $2=$ Tiryns; $5=$ Lerna; 7 = Argos.

In figure $4 \mathrm{~A}$ the probable coastline for the early prehistoric period (neolithic and earlier bronze age) is represented by the line of double-dashes. By the Greco-Roman period the outgrowth of deltaic fill allowed of the construction of the delta harbour sites ( 9 and 10 ).

In figure $4 \mathrm{~B}$ the present day landscape is depicted.

phenomena. Nonetheless this important corollary to the main theory passes unnoticed in the work of Eisma and Raphael.

In their studies of, respectively, the Maeander and Elis coastal plains, seaward extension of river sediments is documented for the centuries preceding the claimed commencement date of the historical fill. Thereby they challenge the chronology and very concept of a natural cycle of alluviation as proposed by Vita-Finzi. However it seems very probable from their descriptions that in both plains deltaic progradation is being confused with total plain aggradation.

One might label this process the 'Struck Sequence', for it is well illustrated by Adolf Struck's account of the discontinuous formation of the alluvial plain of the Thermaic Gulf (Struck 1908). A considerably revised version of the development of this landscape is seen in figure 3 . In figures 4 and 5 provisional reconstructions are presented for the Holocene evolution of two other coastal plains, also based on field observations by the author.

The discontinuous sedimentation and differing physical characteristics of the two major alluvial depositions, with their associated climatic fluctuations, have had a demonstrable influence on cultural 


\section{F. L. Bintliff. MEdTERRANEAN ALLUVIATION}

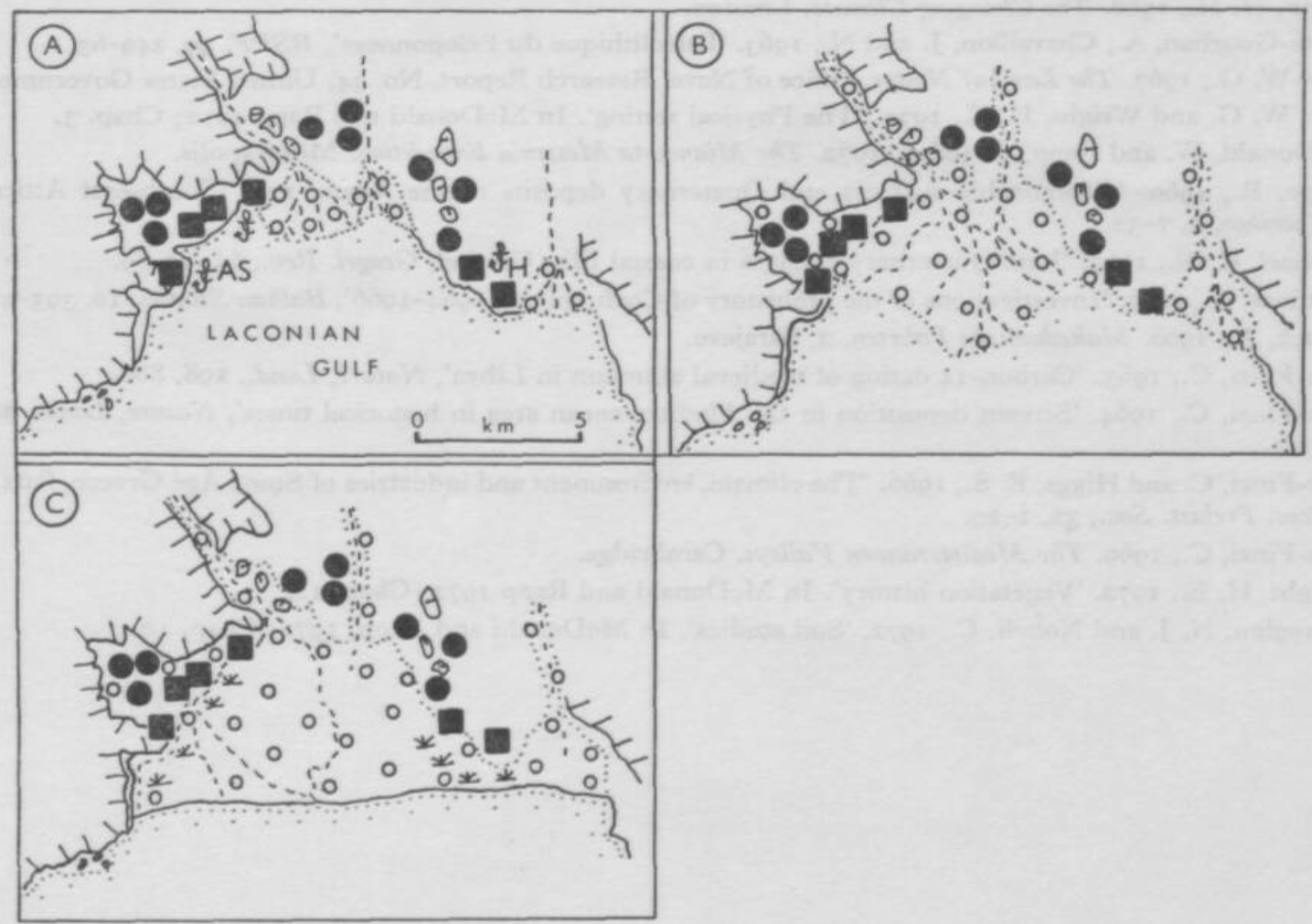

Fig. 5

Provisional reconstructed Holocene evolution of the Helos Plain. Geology symbols as in figure 3, symbols for sites as in figure 4. Period (A) prehistoric and early historic landscape-AS is the bronze age site of Agios Stephanos, H marks the bronze age site probably to be identified with the Homeric town of 'Helos on the sea'. Period (B) the Medieval landscape. Period (C) the present day landscape.

and economic developments in the Mediterranean area that cannot be exaggerated (Bintliff, op. cit.), and should certainly be made a priority field of investigation for interdisciplinary research. Rather than setting up new alluviation schemes at every site, archaeologists and palaeo-geographers must now recognise that independent studies published under other guises actually conform to the VitaFinzi cycle, and they should now direct their efforts to investigate its local manifestations and effects.

\section{BIBLIOGRAPHY}

Bintliff, J. L. 'Sediments and Settlement in Southern Greece'. In Davidson and Shackley (ed.), Geoarchaeology (in press). 'New Approaches to Human Geography: Prehistoric Greece, A Case Study'. In Carter (ed.), The Historical Geography of the Balkans (in press).

Bordes, F., 1968. The Old Stone Age. London.

Butzer, K. W., 1971. Environment and Archaeology. Chicago and N.Y.

Davidson, D., 1971. 'Geomorphology and prehistoric settlement of the Plain of Drama'. Revue de Geomorphologie Dynamique, 20, 22-6.

Eisma, D., 1962. 'Beach ridges near Seljuk, Turkey', Tijdschr. Kon. Aardrk. Gen., 79, 234-46.

Eisma, D., 1964. 'Stream deposition in the Mediterranean area in historical times', Nature, Lond., 203, ro6r. 


\section{THE PREHISTORIC SOCIETY}

Lamb, H. H., r966. The Changing Climate. London.

Leroi-Gourhan, A., Chavaillon, J. and N., 1963. 'Paléolithique du Péloponnese', BSPF, 49, $249-65$.

Loy, W. G., 1967. The Land of Nestor. Office of Naval Research Report, No. 34, United States Government.

Loy, W. G. and Wright, H. E., 1972. 'The Physical setting'. In McDonald and Rapp 1972; Chap. 3.

McDonald, W. and Rapp, G. (eds.), 1972. The Minnesota Messenia Expedition. Minneapolis.

Paepe, R., 1969. 'Geomorphic surfaces and Quaternary deposits of the Adami area (South-east Attica)', Thorikos, 4, 7-52.

Raphael, C. N., 1973. 'Late Quaternary changes in coastal Elis, Greece', Geogrl. Rev., 63, 73-89.

Sordinas, A., r969. 'Investigations of the prehistory of Corfu during 1964-1966', Balkan Studies, ro, 393-424.

Struck, A., 1908. Makedonische Fahrten, 2, Sarajevo.

Vita-Finzi, C., r963. 'Carbon-14 dating of medieval alluvium in Libya', Nature, Lond., r98, 880.

Vita-Finzi, C., 1964. 'Stream deposition in the Mediterranean area in historical times', Nature, Lond., 202, 1324 .

Vita-Finzi, C. and Higgs, E. S., r966. 'The climate, environment and industries of Stone Age Greece, Part 2', Proc. Prehist. Soc., 32, 1-29.

Vita-Finzi, C., 1969. The Mediterranean Valleys. Cambridge.

Wright, H. E., 1972. 'Vegetation history'. In McDonald and Rapp 1972; Chap. 12.

Yassoglou, N. J. and Nobeli, C., 1972. 'Soil studies'. In McDonald and Rapp, 1972; Chap. 10. 